\title{
Stability of cefacetrile in milk samples with various fat content
}

\author{
Edyta M. Grzelak • Irena M. Choma
}

Received: 15 November 2012/Revised: 20 May 2013/ Accepted: 25 May 2013/Published online: 20 June 2013

(C) The Author(s) 2013. This article is published with open access at Springerlink.com

\begin{abstract}
The consumers should have access to food that is safe and free of contaminants. Unfortunately, the wide use of antibiotics in livestock, not only for medicinal purposes but also as illegal feed additives, may be the reason for emergence of the antibiotic residues in foodstuffs of animal origin. Milk is one of the most essential nutrients for humans during their lifetimes. Failure of the withdrawal periods, or what is highly prohibited but in spite of this increasingly practiced, addition of the antibiotics to milk in order to prolong its freshness, may lead to occurrence of their residues. Cefacetrile is a first generation cephalosporin that is commonly use for the treatment of bovine mastitis. The aim of this work was to determine the stability of cefacetrile in milk samples of different fat content, that is, $0,2,3.2 \%$ UHT, $2 \%$ pasteurized and $\sim 3.9 \%$ raw cattle milk, for 5 days. Two chromatographic methods were applied and compared for this purpose, that is, thin-layer chromatography and highperformance liquid chromatography. According to the results coming from HPLC-UV analysis, the stability of cefacetrile increase with the increase in the fat mass content in UHT milk. The cefacetrile level in pasteurized and raw cattle milk is similar to that in $3.2 \%$ UHT milk. For the TLC method, this relation can be observed only in the second day of the analysis. The spiked milk samples analyzed by HPLC were deproteinized with $\mathrm{MeCN}$ and stored for 5 days of the experiment. Whereas, in the TLC-UV method, the spiked milk samples prepared in the first day of experiment were analyzed directly, without deproteinization. The lower stability of cefacetrile in milk samples
\end{abstract}

E. M. Grzelak ( $\varangle)$ · I. M. Choma

Department of Chromatographic Methods, University of Maria Curie-Skłodowska, M. Skłodowska Sq. 3, 20-031 Lublin, Poland e-mail: edyta.lbn@wp.pl observed from the TLC analysis can be related to its partial enzymatic decomposition.

Keywords Chromatography $\cdot$ Cefacetrile $\cdot$ Milk · Veterinary drug residues

\section{Introduction}

Milk is a complex body fluid that is a complete nutrient for all newborn mammals and the sole food in the early stages of their development [1]. It can be considered as one of the most important feeding resources for human, taking into account all the milk fermentation and transformation products, as it contains essential nutritional, immunological and biologically active components [2]. The bioactive functions are carried out mainly by milk proteins or peptides through a protein-protein interaction mechanism [3]. The bioactive peptides may affect the major body systems, like the cardiovascular, digestive, immune and nervous systems [4]. Other bioactive substances that milk contains include hormones, oligosaccharides, fucosylated oligosaccharides, growth factors and gangliosides.

Bovine milk is composed of approximately $87 \%$ water, $5 \%$ lactose, $4 \%$ lipid, $3.2 \%$ protein and $0.7 \%$ mineral salts [5]. However, the composition varies depending on various factors, such as a stage of lactation or animal nutrition. The widespread use of antibiotics in livestock, to prevent or treat bacterial infections, can lead to the presence of their residues in meat and dairy products. Furthermore, antibiotics are frequently added to feed as growth promoters or directly to milk to prolong its freshness [6]. The occurrence of antibiotic residues in raw milk may inhibit starter cultures used in production of dairy products, such as a cheese or yogurt and in the consequence causes 
costly economic losses to the diary industry [7]. Pasteurization and other forms of heat treatment remove pathogenic microorganisms but have limited effects on antibiotic residues [8]. Most of all, the residues of antibiotics might have undesirable effects on consumer health, causing allergic reactions in hypersensitive individuals or promoting bacterial resistance.

To prevent the consumers and keep the antibiotic residues out of the food chain, the regulatory authorities have established the withdrawal periods for antibiotics that must be observed by producers before the milk from the treated cows can be sent to the market. Maximum residue limits (MRLs) of antibiotics in foodstuff of animal origin, taking into account the daily acceptable intake of each antibiotic and maximum food intakes, were also established. In the EU countries, monitoring of antibiotic residues in food is regulated in Council Directive 96/23/ EC 1996 [9].

Cefacetrile belongs to a first generation of cephalosporins and exerts higher activity against Gram-positive bacteria than against Gram-negative ones [10]. This antibiotic is widely used in veterinary medicine, for example, for treatment of bovine mastitis. Therefore, there is a threat of emergence of its residues in meat or milk intended for the consumption. The withdrawal period for commercially available products containing cefacetrile equals 3 days for milk and 7 days for meat. The established MRL of cefacetrile in bovine milk equals $125 \mu \mathrm{g} \mathrm{kg}^{-1}$.

The aim of this study was to investigate the stability of cefacetrile in milk samples varying in fat mass contents and origin, that is, $0 \%$ UHT, $2 \%$ UHT, $3.2 \%$ UHT, $2 \%$ pasteurized and $\sim 3.9 \%$ raw cattle milk, for 5 days. Two chromatographic methods were applied and compared for this purpose: Thin-layer chromatography that does not require special sample preparation, and high-performance liquid chromatography for which the preparation of milk samples is necessary before the analysis.

\section{Materials and methods}

\section{Reagents}

Standard of cefacetrile was purchased from Novartis Animal Health (Basel, Switzerland). Hexane, ethyl acetate, toluene, methanol $(\mathrm{MeOH})$, phosphoric acid and $98 \%$ formic acid were of analytical grade and were purchased from $\mathrm{POCH}$ (Gliwice, Poland). Potassium phosphate monobasic was from Chempur (Piekary Śląskie, Poland). Acetonitrile (MeCN) HPLC grade was purchased from Merck (Darmstadt, Germany).
Table 1 Composition and properties of milk samples

\begin{tabular}{|c|c|c|c|c|c|}
\hline $\begin{array}{l}\text { Composition } \\
\text { (in } 100 \mathrm{~mL} \text { ) }\end{array}$ & $\begin{array}{l}0 \% \text { fat } \\
\text { UHT } \\
\text { milk }\end{array}$ & $\begin{array}{l}2 \% \text { fat } \\
\text { UHT } \\
\text { milk }\end{array}$ & $\begin{array}{l}3.2 \% \\
\text { fat } \\
\text { UHT } \\
\text { milk }\end{array}$ & $\begin{array}{l}\text { Pasteurized } \\
2 \% \text { milk }\end{array}$ & $\begin{array}{l}\text { Raw } \\
\text { cattle } \\
\text { milk }\end{array}$ \\
\hline $\begin{array}{l}\text { Energy values } \\
(\mathrm{kJ}) /(\mathrm{kcal})\end{array}$ & $134 / 32$ & $210 / 50$ & $252 / 60$ & $193 / 46$ & $\begin{array}{r}277 / \\
66\end{array}$ \\
\hline Protein $(\mathrm{g})$ & 3.2 & 3.2 & 3.2 & 2.9 & 3.2 \\
\hline $\begin{array}{l}\text { Carbohydrates } \\
\text { (g) }\end{array}$ & 4.7 & 4.7 & 4.7 & 4.3 & 4.8 \\
\hline Lipids (g) & 0.0 & 2.0 & 3.2 & 2.0 & 3.9 \\
\hline
\end{tabular}

Standard solutions of cefacetrile

The standard stock solution at $1.0 \mathrm{mg} \mathrm{mL}^{-1}$ of cefacetrile was prepared in methanol (for TLC-UV analysis) or in $\mathrm{MeCN} /$ water (15:85) (for HPLC-UV analysis). The working standard solutions were prepared by appropriate dilution of the standard stock solution.

Milk samples

UHT milk with 0,2 or $3.2 \%$ fat mass content and pasteurized milk with $2 \%$ fat mass content were purchased from the local shop in Lublin, Poland. The raw cattle milk was obtained from the local farmer (Lubelskie, Poland) (Table 1).

The milk samples containing cefacetrile at a concentration of 1.0 and $0.5 \mathrm{mg} \mathrm{mL}^{-1}$ were prepared by fortification of $1.0 \mathrm{~mL}$ of milk with 1.0 or $0.5 \mathrm{~g}$ of the antibiotic, respectively. The milk samples containing cefacetrile at concentrations of $0.1 \mathrm{mg} \mathrm{mL}^{-1}$ were prepared by fortification of $0.9 \mathrm{~mL}$ of milk with $0.1 \mathrm{~mL}$ of the working standard solution at concentration of $1.0 \mathrm{mg} \mathrm{mL}^{-1}$. The milk spiked with cefacetrile was applied directly, without any pretreatment, on TLC plates.

For HPLC-UV analysis, the milk samples were deproteinized as follows: $1 \mathrm{~mL}$ of $\mathrm{MeCN}$ was added to $1 \mathrm{~mL}$ of each milk sample. Next, the samples were vortex for $20 \mathrm{~s}$ and then, centrifuged at $8,400 \mathrm{~g}$ for $15 \mathrm{~min}$. The supernatants were transferred to the new vials and stored at $-20{ }^{\circ} \mathrm{C}$ in freezer during 5 days of the experiment. The blank milk samples were prepared according to the same procedure but without addition of the cefacetrile.

Thin-layer chromatography with UV detection (TLC-UV)

TLC analysis was performed on precoated TLC Si60 $\mathrm{F}_{254}$ glass-backed plates $20 \times 10 \mathrm{~cm}$ with concentrating zone $2.5 \times 10 \mathrm{~cm}$ from Merck (Darmstadt, Germany). DS-L chambers were obtained from Chromdes (Lublin, Poland). 

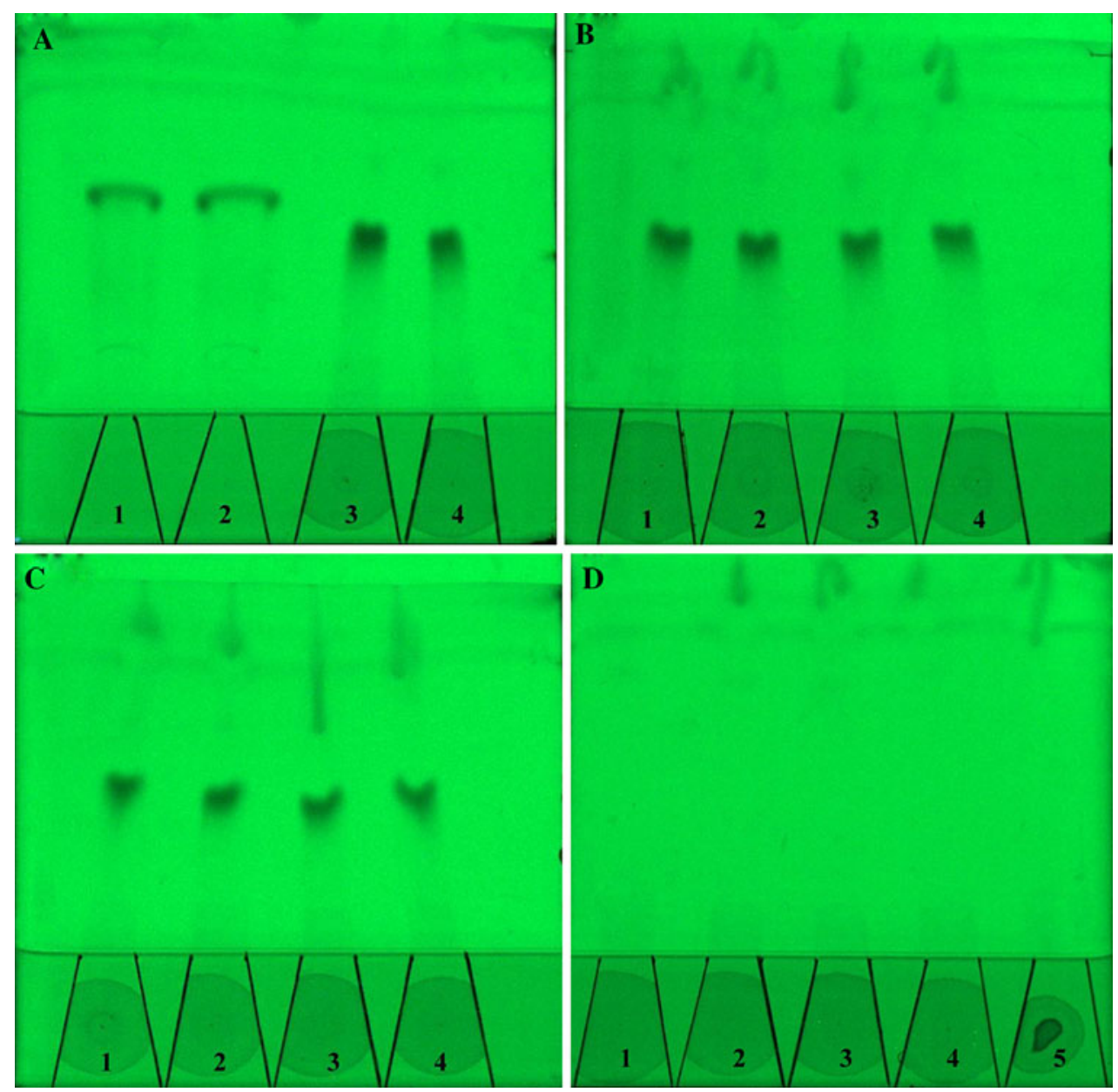

Fig. 1 TLC chromatogram of: a $(1,2)$ cefacetrile methanol standard $\left(1.0 \mathrm{mg} \cdot \mathrm{mL}^{-1}\right),(3,4) 0 \%$ UHT milk spiked with cefacetrile at $1.0 \mathrm{mg} \mathrm{mL}^{-1} ; \mathbf{b}(1,2) 2 \%$ UHT milk spiked with cefacetrile at $1.0 \mathrm{mg} \cdot \mathrm{mL}^{-1},(3,4) 3.2 \%$ UHT milk spiked with cefacetrile at $1.0 \mathrm{mg} \cdot \mathrm{mL}^{-1}$; c $(1,2) 2 \%$ pasteurized milk spiked with cefacetrile at $1.0 \mathrm{mg} \cdot \mathrm{mL}^{-1},(3,4)$ raw cattle milk spiked with cefacetrile at

$1.0 \mathrm{mg} \cdot \mathrm{mL}^{-1}$; d blank milk samples (1) $0 \%$ UHT milk, (2) $2 \%$ UHT milk, (3) $3.2 \%$ UHT milk, (4) $2 \%$ pasteurized milk, (5) raw cattle milk. The TLC Si60 $\mathrm{F}_{254}$ plates with concentrating zone were predeveloped with hexane, next with mobile phase methanol-tolueneethyl acetate $-98 \%$ formic acid $(5: 20: 65: 10, \mathrm{v} / \mathrm{v} / \mathrm{v} / \mathrm{v})$. The volume applied was $10 \mu \mathrm{L}$

The areas of the spots were measured using Reprostar 3 cefacetrile at concentration of $0.1,0.5,1.0 \mathrm{mg} \mathrm{mL}^{-1}$ were Video Camera from Camag (Muttenz, Switzerland). The plate images were documented by DigiStore 2 Documentation System (Camag) and analyzed using winCATS software version 1.4.1 (Camag).

A volume of $10 \mu \mathrm{L}$ of the cefacetrile standard solutions and the milk samples spiked at the same concentration level were applied on the TLC plate in the middle of trapezoidal-shaped regions created by the incision of the concentrating zone. Next, the TLC plates were set into DS$\mathrm{L}$ chambers and predeveloped with hexane to remove lipids from the milk samples. After air-drying, the TLC plates were developed to a distance of $9.0 \mathrm{~cm}$ with a proper solvent system, that is, methanol-toluene-ethyl acetate$98 \%$ formic acid (5:20:65:10). The areas of the cefacetrile spots were measured at $254 \mathrm{~nm}$ using the video camera. The standard solutions and milk samples spiked with analyzed twice on first, second, third and fifth day after preparation.

High-performance liquid chromatography with UV detection (HPLC-UV)

HPLC-UV analysis was carried out using LC-10AD pump (Shimadzu, Kyoto, Japan) equipped with UV/VIS155 detector from Gilson (Middleton, USA). The separation was performed on PhenoSphere-NEXT column ( $5 \mu \mathrm{m}$, $4.6 \times 150 \mathrm{~mm}$ ) from Phenomenex (Torrance, USA) using $\mathrm{MeCN} /$ water $\left(\mathrm{pH} \mathrm{3}\right.$, adjusted with $\left.\mathrm{H}_{3} \mathrm{PO}_{4}\right)(15: 85$, v/v) as the mobile phase at a flow-rate of $1.0 \mathrm{~mL} \mathrm{~min}^{-1}$ at the ambient temperature. The injection volume was $10 \mu \mathrm{L}$. The data were collected and analyzed using CSW32 Chromatography Station from DataApex (Prague, Czech 
Fig. 2 HPLC chromatograms obtained for $0 \%$ UHT milk sample containing cefacetrile $\left(1 \mathrm{mg} \mathrm{mL}^{-1}\right)$; analyzed in the first, second, third and fifth day after preparation

$\left(t_{R}=4,62 \mathrm{~min}\right)$. PhenoSphereNEXT column $(5 \mu \mathrm{m}$,

$4.6 \times 150 \mathrm{~mm})$, mobile phase: $\mathrm{MeCN} /$ water $(\mathrm{pH} \mathrm{3}$, adjusted with $\left.\mathrm{H}_{3} \mathrm{PO}_{4}\right)(15: 85$, v/v), flowrate of $1.0 \mathrm{~mL} \mathrm{~min}{ }^{-1}$. The injection volume was $10 \mu \mathrm{L}$

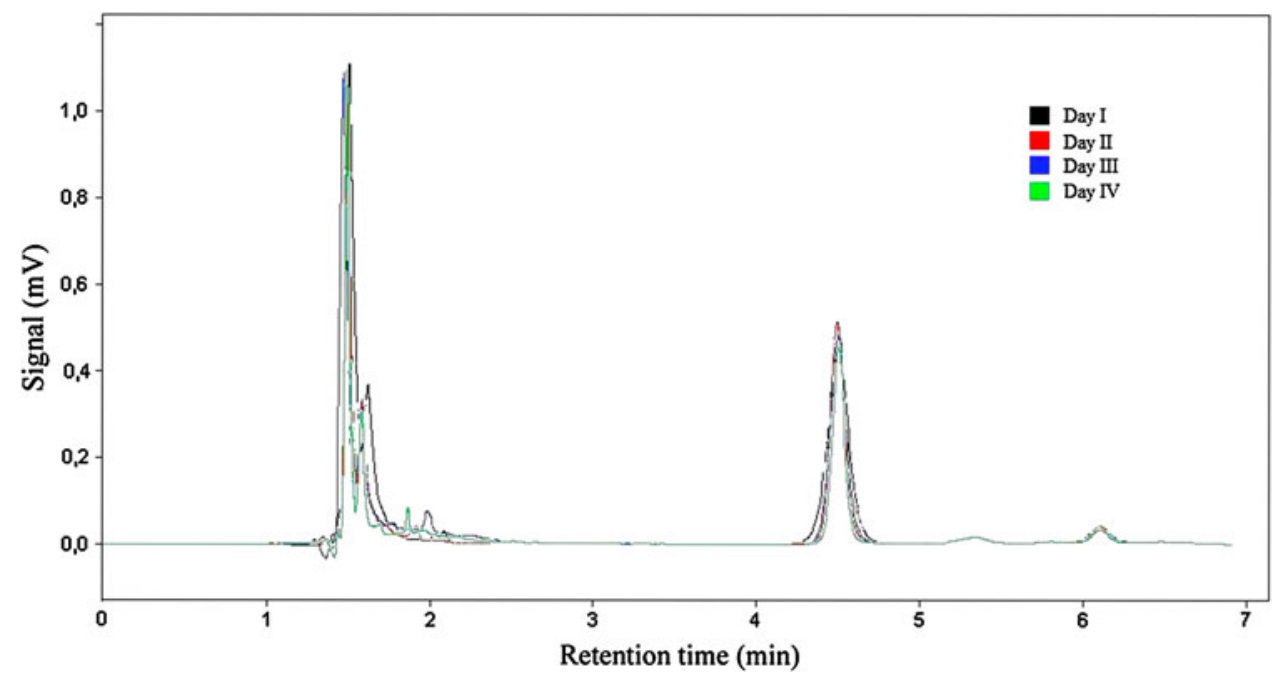

Republic). The standard solutions and deproteinized milk samples spiked with cefacetrile at concentration of $0.1,0.5$, $1.0 \mathrm{mg} \mathrm{mL}{ }^{-1}$ were analyzed twice on first, second, third and fifth day after preparation.

\section{Results and discussion}

TLC is a simple, rapid and cheap analytical method. One of the biggest advantages of this method is no need for special sample preparation. However, this may lead to occurrence of crooked front of the mobile phase or tailing effect, particularly, when the complex matrix samples are analyzed. In order to obtain a regular front of developing solvent, standard solutions and milk samples were applied in the middle of trapezoidal-shaped regions prepared by incision in the TLC plate's concentrating zone $[11,12]$. During the development of the chromatogram, large protein molecules have remained on the concentrating zones. To avoid tailing of the cefacetrile spots caused by the presence of the milk lipids, predevelopment with a lipophilic solvent was done before the development with a proper solvent system. Cefacetrile was initially concentrated on the border of wide and narrow porous silica gel, and then, as a narrow band migrate along the TLC plate free of the matrix (see Fig. 1).

The stability of cefacetrile in milk samples with various fat content and of different origin was studied using TLCUV and HPLC-UV (see Fig. 2) methods on the first, second, third and fifth day after preparation of the samples. Table 2 compares the results obtained for the both methods.

The stability of cefacetrile decreases in the subsequent days of the analysis regardless to the type of the milk samples. Figure 3 presents the recovery of cefacetrile in milk samples, calculated relative to the samples prepared in the first days of the experiment.
The results of the recoveries of cefacetrile in milk samples vary for both methods applied. According to TLC-UV method, on the fifth day of experiment, the highest recoveries of the antibiotic were obtained for $2 \%$ pasteurized milk, followed (in order from the highest to the lowest recoveries): by raw cattle milk and $2 \%$ UHT, $0 \%$ UHT and $3.2 \%$ UHT. While, according to the results of HPLC-UV analysis, the recoveries of cefacetrile decrease in the following order (from the highest to the lowest recoveries): $2 \%$ pasteurized milk, raw cattle milk, $3.2 \%$ UHT, $2 \%$ UHT and $0 \%$ UHT. This order is characteristic for the all days of the experiment and indicates that the stability of cefacetrile increases with the increase in the fat mass content in UHT milk. The stability of the antibiotic in pasteurized and raw cattle milk remains at the similar level as in $3.2 \%$ UHT milk. In case of TLC method, this relation can be observed only for the results obtained on the second day of the analysis. On the third and fifth day, the stability of cefacetrile significantly decreases in $3.2 \%$ UHT and raw cattle milk. The percentage loss of the antibiotic in milk samples for TLC-UV is even five times bigger than for HPLC-UV. The differences in the results obtained may refer to the fact that in HPLC-UV method, the milk samples deproteinized with $\mathrm{MeCN}$ were analyzed, whereas in TLC-UV method, the milk samples were analyzed directly, without any special preparation. The lower stability of cefacetrile in samples for TLC analysis can be connected with its partial decomposition in milk matrix that is related probably to milk enzymatic system.

The calibration curves were constructed for cefacetrile standard solutions and milk samples by plotting the concentration of cefacetrile in standard solution/milk versus the area of spot (for TLC-UV) or peak area (for HPLC-UV). The calibration curves for HPLC-UV method show good linearity both for cefacetrile standard solution $(y=71.673$ 
Table 2 The mean peak area of cefacetrile obtained by TLC-UV and HPLC-UV analysis, within 5 days of the experiment; $n=4$

\begin{tabular}{|c|c|c|c|c|c|c|}
\hline & \multicolumn{3}{|l|}{ TLC-UV } & \multicolumn{3}{|c|}{ HPLC-UV } \\
\hline & \multicolumn{6}{|c|}{ Concentration of cefacetrile $\left(\mu \mathrm{g} \mathrm{mL}^{-1}\right)$} \\
\hline & 10 & 50 & 100 & 10 & 50 & 100 \\
\hline \multicolumn{7}{|c|}{ UHT milk with $0 \%$ fat content } \\
\hline Day I & $3,431.80$ & $15,392.00$ & $23,827.05$ & 542.31 & $3,118.17$ & $6,149.52$ \\
\hline Day II & $3,374.20$ & $13,140.95$ & $21,132.10$ & 536.64 & $3,022.31$ & $6,057.85$ \\
\hline Day III & $2,846.70$ & $11,848.90$ & $20,816.60$ & 523.34 & $2,984.86$ & $5,924.39$ \\
\hline Day V & $2,618.15$ & $11,037.65$ & $17,924.70$ & 517.63 & $2,840.71$ & $5,885.50$ \\
\hline \multicolumn{7}{|c|}{ UHT milk with $2 \%$ fat content } \\
\hline Day I & $3,812.65$ & $14,497.55$ & $24,758.15$ & 561.16 & $2,999.52$ & $6,154.87$ \\
\hline Day II & $2,903.10$ & $14,116.15$ & $23,270.20$ & 542.27 & $2,814.69$ & $5,958.85$ \\
\hline Day III & $2,797.85$ & $13,935.05$ & $22,421.10$ & 532.02 & $2,749.57$ & $5,784.78$ \\
\hline Day V & $2,681.35$ & $13,451.10$ & $19,284.00$ & 530.98 & $2,677.71$ & $5,646.55$ \\
\hline \multicolumn{7}{|c|}{ UHT milk with $3.2 \%$ fat content } \\
\hline Day I & $3,774.15$ & $19,278.45$ & $23,387.05$ & 590.10 & $3,147.12$ & $6,329.06$ \\
\hline Day II & $2,479.10$ & $18,009.90$ & $22,049.08$ & 580.63 & $3,081.79$ & $6,270.36$ \\
\hline Day III & $2,025.60$ & $16,142.65$ & $20,304.40$ & 570.66 & $3,026.91$ & $6,187.64$ \\
\hline Day V & $1,905.20$ & $9,316.95$ & $17,357.55$ & 558.96 & $2,949.59$ & $6,053.23$ \\
\hline \multicolumn{7}{|c|}{ Pasteurized milk with $2 \%$ fat content } \\
\hline Day I & $3,351.50$ & $16,505.55$ & $23,632.90$ & 582.82 & $3,148.27$ & $6,171.06$ \\
\hline Day II & $2,821.70$ & $13,626.75$ & $22,840.10$ & 561.33 & $3,084.60$ & $6,115.40$ \\
\hline Day III & $2,553.30$ & $13,183.30$ & $22,539.70$ & 550.82 & $3,007.80$ & $6,060.78$ \\
\hline Day V & $1,959.30$ & $12,675.20$ & $19,867.70$ & 528.30 & $2,937.45$ & $5,979.56$ \\
\hline \multicolumn{7}{|c|}{ Raw cattle milk $\sim 3.9 \%$ fat content } \\
\hline Day I & $3,248.55$ & $15,253.00$ & $23,341.20$ & 586.40 & $3,033.87$ & $6,212.47$ \\
\hline Day II & $2,644.90$ & $13,927.65$ & $22,439.70$ & 573.63 & $2,900.94$ & $6,130.20$ \\
\hline Day III & $2,545.80$ & $12,349.55$ & $19,147.85$ & 561.84 & $2,897.23$ & $6,084.90$ \\
\hline Day V & $2,349.70$ & $10,533.05$ & $18,619.35$ & 549.86 & $2,861.28$ & $5,944.88$ \\
\hline
\end{tabular}

$\left.-43.269 ; R^{2}=0.9996\right)$ and milk samples (e.g., raw cattle milk: $\left.y=62.555-58.705 ; R^{2}=0.9999\right)$. The calibration curves for TLC-UV show good linearity only for cefacetrile standard solutions $\left(y=190.67+514.83 ; R^{2}=0.9926\right)$, whereas for milk samples, the linearity is worse (e.g., raw cattle milk: $y=220.73+2175.2 ; R^{2}=0.9693$ ).

The applied TLC-UV method did not involve special sample preparation. The milk samples were spotted directly on the TLC plates, developed with hexane in order to remove the milk lipids and then developed with a proper solvent system. Worse linearity obtained for the milk samples by TLC-UV indicate that for more complex matrix, special sample preparation is necessary even before semiquantitative TLC analysis. Good linearity obtained for cefacetrile standard solutions by TLC-UV confirms that this method is appropriate for pharmaceutical analysis.

\section{Conclusion}

TLC-UV and HPLC-UV were applied for the studies of the stability of cefacetrile in milk samples and standard
Fig. 3 The recoveries (\%) of cefacetrile in milk samples $\left(100 \mu \mathrm{g} \mathrm{mL}^{-1}\right)$ determined by a TLC-UV and b HPLC-UV methods within 5 days of the experiment 
solution. TLC is a simple, cheap and rapid method that allows semiquantitative determination of analytes. HPLC is a quantitative method, with greater sensitivity than TLC, however, which requires expensive equipment and use of large amounts of reagents. The significant difference between the two methods is no need for special sample preparation prior to the TLC analysis, whereas sample preparation is necessary prior to the HPLC analysis. The selection of the method applied for the analysis of contaminated food samples should depend on the information to be achieved.

The results obtained proved that for a quantitative analysis, HPLC method is preferred. However, TLC seems to be more appropriate method to study the stability of the analytes in real food samples. The degradation of cefacetrile in milk samples depends on time, fat content and milk enzymatic system which do not any longer exist in the deproteinized samples for HPLC analysis. TLC enables the direct studies without necessity of special sample pretreatment that can affect the results of the analysis.

\section{Conflict of interest None.}

Compliance with Ethics Requirements This article does not contain any studies with human or animal subjects.

Open Access This article is distributed under the terms of the Creative Commons Attribution License which permits any use, distribution, and reproduction in any medium, provided the original author(s) and the source are credited.

\section{References}

1. Emmett PM, Rogers IS (1997) Properties of human milk and their relationship with maternal nutrition. Early Hum Dev 49:S7-S28

2. Wong WMJ, de Souza R, Kendall CWC, Emam A, Jenkins DJA (2006) Colonic health: fermentation and short chain fatty acids. J Clin Gastroenterol 40:235-243

3. Roncada P, Piras C, Soggiu C, Turk R, Urbani A, Bonizzi L (2012) Farm animal milk proteomics. J. Proteomics 75:4259-4274

4. Korhonen H, Pihlanto A (2006) Bioactive peptides: production and functionality. Int Dairy J 16:945-960

5. Séverin S, Wenshiu X (2005) Milk biologically active components as neutraceuticals. Crit Rev Food Sci Nutr 45:645-656

6. Samanidou V, Nisyriou S (2008) Multi-residue methods for confirmatory determination of antibiotics in milk. J Sep Sci 31: 2068-2090

7. Grunwald L, Petz M (2003) Food processing effects on residues: penicillins in milk and yoghurt. Anal Chim Acta 483:73-79

8. Moats WA (1998) Inactivation of antibiotics by heating in foods and other substrates: a review. J Food Prot 51(6):491-497

9. Council Directive 96/23/EC (1996) European Commission, Council Directive 96/23/EC of 29 April 1996 on measures to monitor certain substances and residues thereof in live animals and animal products and repealing Directives 85/358/EEC and Decision 89/187/EEC and 91/664/EEC, Off J Eur Union, L125 10

10. EMEA (2000) The European Agency for the Evaluation of Medical Products Paper, No EMEA/MRL/754/00-FINAL July 2000

11. Choma I, Grenda D, Malinowska I, Suprynowicz Z (1999) Determination of flumequine and doxycycline in milk by a simple thin-layer chromatographic method. J Chromatogr B 734:7-14

12. Grzelak EM, Malinowska I, Choma IM (2009) Determination of cefacetrile and cefuroxime residues in milk by thin-layer chromatography. J Liq Chrom Relat Tech 32(14):2043-2049 